\title{
THE SYSTEM FOR THE STUDY OF HEALTH AND THE SAFETY OF THE POPULATION ON WATER QUALITY OF THE CACHOEIRA GRANDE WATER LOCATED IN THE SÃO JORGE NEIGHBORHOOD IN MANAUS CITY
}

\author{
Leandro Augusto da Silva ${ }^{1}$, David Barbosa de Alencar ${ }^{2}$ and Darlei dos Anjos Lavor ${ }^{3}$
}

${ }^{1}$ Blauro Cardoso de Mattos Higher Education Institute - FASERRA. Manaus-Amazonas, Brazil.

${ }^{2}$ Galileo Institute of Technology and Education of the Amazon - ITEGAM. Manaus-Amazonas, Brazil.

${ }^{3}$ Northern University Center - UNINORTE. Manaus-Amazonas, Brazil.

Email: leandro_silvaa01@outlook.com, david002870@hotmail.com, darleilavor27@gmail.com

Received: Aug 14 ${ }^{\text {th }}, 2019$

Accepted: Aug 30th, 2019

Published: December 02 ${ }^{\text {th }}, 2019$

Copyright (C2016 by authors and Galileo Institute of Technology and Education of the Amazon (ITEGAM).

This work is licensed under the Creative Commons Attribution International License (CC BY 4.0).

https://creativecommons.org/licen ses/by/4.0/

\begin{abstract}
For a long time, water was considered only as a means of consumption for the survival of living beings. I was not concerned about its quality for its own consumption. But over time, due to many deaths from drinking non-potable water, there have been various adaptations and technologies have emerged for better consumption and treatment of this material. The objective of this research is to analyze the water quality of the Cachoeira Grande stream located in the São Jorge neighborhood in the city of Manaus in order to know the health and safety of the residents and the general population of the Amazonian capital. The analyzes were performed through the physical, chemical and microbiological characteristics of the water collected in three distinct points, near the margins of the stream. The results analyzed were already obvious and yet were disturbing, since there is a great neglect that concerns society in general.
\end{abstract}

Keywords: Water, Quality, Features.

\section{Open Acetes:}

\section{INTRODUTION}

The most precious asset that the world's population has is water. Through its use, it meets numerous personal needs involving economic activities such as social, agricultural and industrial. It is through her that we have been able to stay alive since the beginning of time.

[1] The water is a fundamental substance in biological functions as it acts as a solvent for human body fluids and as a transport medium for ions and molecules in cellular functions, as well as regulating body temperature. About $70 \%$ of the human body is made up of water. [2] Drinking water is generally constant in its composition, although some microbiological and physicochemical variables may interfere with quality. The presence of pathogens in water and / or how they occur: collection, transportation, storage and general use are factors that compromise the quality of water consumption.

However, its misuse has been more studied in recent years due to the concern with its quality. [3] There is a need to frame water resources at different quality levels as they are assigned to multiple uses.

The main sources of contamination through water resources are sewage from untreated cities that are discharged into rivers and lakes; landfills that affect groundwater, rain-fed pesticides being dragged into rivers and lakes, miners that release chemicals such as mercury into rivers and streams, and industries that use rivers as carriers of their waters toxic, waste showing that such actions bring problems that are difficult to solve [4].

Given the above, this research performs water quality analyzes of the Cachoeira Grande stream in the São Jorge neighborhood of Manaus. Within the scope of this project, the health and safety of the population, living there is determined.

\section{BIBLIOGRAPHICAL REFERENCE}

\section{II.1 WATER QUALITY}

Water is one of the most widely distributed compounds in the earth's crust and covers about $70 \%$ of it. It is the essential and indispensable element for the maintenance of life, not only for its 
peculiar characteristics, but for the fact that no metabolic process occurs without its direct or indirect action. Under these conditions, it is essential that its presence in the environment be in appropriate quantity and quality for its subsequent use [5].

[6] The geological, geomorphological and vegetation conditions in the drainage basin, the performance of terrestrial and aquatic ecosystems and human action may alter water quality. Anthropogenic actions are those that have the greatest impact due to the release of pollutant loads in water systems and the change in land use ends up causing direct interventions in the river system.

The term water quality does not only address the state of water purity, but also the physical, chemical and biological characteristics and depending on these characteristics, various destinations for water are determined. The water quality of a given water resource is evaluated depending on the substances present in the water, called water quality parameters. Such substances characterize the conditions in which water are found, for various uses, including its preservation in the environment [7].

The main concern regarding water quality is certainly related to human consumption. One of the biggest risks to our health is fecal contamination. This is why microbiological analysis of water is so important [8].

[8] Worldwide contaminated water, often associated with poor sanitation, kills about 1.6 million people during the year. According to the Ministry of Health, the cost generated for the treatment of diseases transmitted by contaminated water in Brazil is equivalent to US \$2.7 billion per year.

Figure 1 below shows the reality of water quality in most streams in the Amazonian capital in the middle of urbanization.

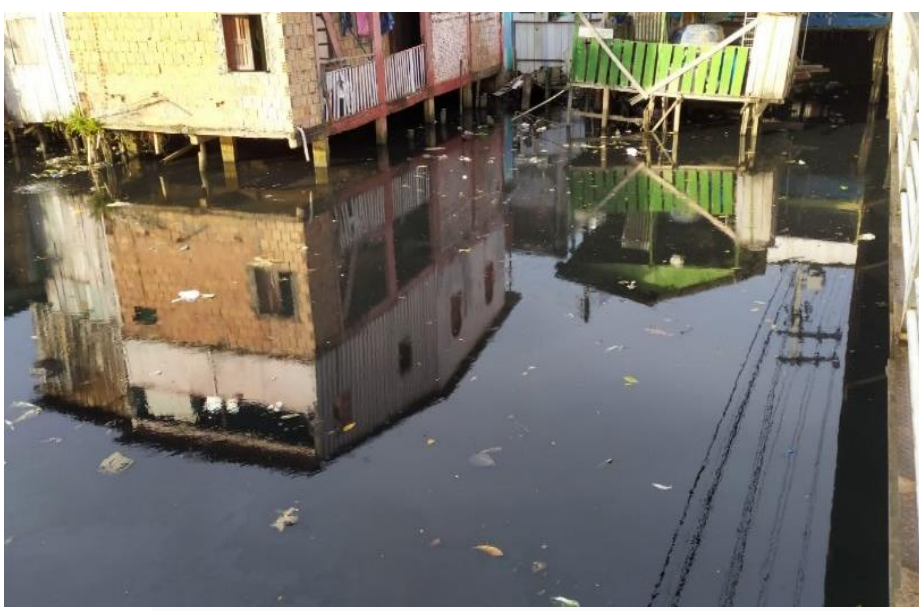

Figure 1: Water quality of the Cachoeira Grande stream in the São Jorge neighborhood in Manaus with the naked eye. Source: Authors, (2019).

\section{II.2 ENVIRONMENTAL DEGRADATION AND SOURCES OF POLLUTION}

The legislation that conceptualizes environmental degradation in Brazil is Law N $N^{\circ} 6.938$ of August 31, 1981, which provides for the National Environmental Policy, which deals with the adverse alteration of environmental characteristics [9]. With the increasing degradation in watersheds, aquatic ecosystems end up serving as deposits of a great diversity and quantity of man-made pollutants, whether by air, soil or directly in the watersheds. Thus, pollution of the aquatic environment, caused directly or indirectly by man, produces deleterious effects such as: harm to living beings, danger to human health, negative effects on aquatic activities (fishing, leisure, etc.) and damage to water quality with respect for use in agriculture, industry and other economic activities [10].
Figure 2 below demonstrates the lack of awareness of both the population and public agencies regarding the neglect of Urban Solid Waste (MSW) in the streams of Manaus.

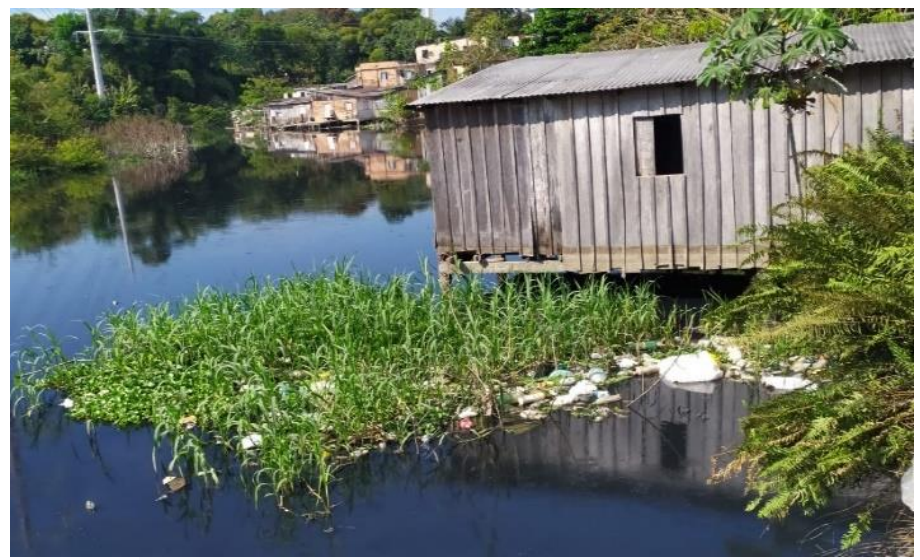

Figure 2: Urban Solid Waste (MSW) disposed in the Cachoeira

Grande stream in the São Jorge neighborhood of Manaus. Source: Authors, (2019).

\section{II.3 CONSUMPTION AND NON-CONSUMPTIVE USES OF WATER}

The importance of water is not only related to its functions in nature, but to its role in human health, economy and quality of life. From a cultural point of view, water also plays an important role in building and growing civilizations, such as the Mesopotamian and Egyptian civilizations that developed along the Tigris and Euphrates and Nile rivers, respectively [11].

[12] Water uses are classified as consumptive and nonconsumptive uses. This classification occurs according to the amount of water demanded and the qualitative and quantitative losses generated after the uses.

[13] The consumptive use is that in which a certain amount of water is withdrawn from the springs, which after being used, is returned in smaller quantity and / or with inferior quality, causing qualitative and quantitative damages. [14] In Brazil, the consumptive uses of water are distributed in irrigation (63\%), human supply (18\%), industrial sector (14\%) and animal use (5\%). The high water consumption in this type of activity causes significant losses, leading to waste and contamination of both surface and groundwater. In fact, efficient use in the irrigation process can control the damage caused to water resources and soil.

Water from industrial use can carry toxic wastes such as heavy metals and debris from decomposing materials.

Non-consumptive uses use water in their own springs without having to remove it from the catchment system; or after their capture, return fully to their sources. For example, electricity generation, navigation, effluent dilution, fishing preservation of flora and fauna and recreation [15].

They are directly related to water quality, especially those intended for primary contact recreation, such as swimming, water skiing and diving, which must follow the standards set by [16]. However, all these activities (advisory and non-advisory), to a greater or lesser extent, pose risks to the aquatic environment when handled without proper control and enforcement.

\section{MATERIAL AND METHODS}

\section{III.1 AREA OF STUDY}

This study was conducted in the São Jorge neighborhood, west of the Amazonian capital - Manaus. Its geographical 
coordinates of latitude are $3^{\circ} 106^{\prime} 458^{\prime \prime}$ South and of longitude are $60^{\circ} 029^{\prime} 169^{\prime}$ "West. According to the census of the Brazilian Institute of Geography and Statistics (IBGE), its population is 21,643 inhabitants [17]. The figure 3 below shows the territory of the neighborhood highlighted in red with about 292 hectares of territory.

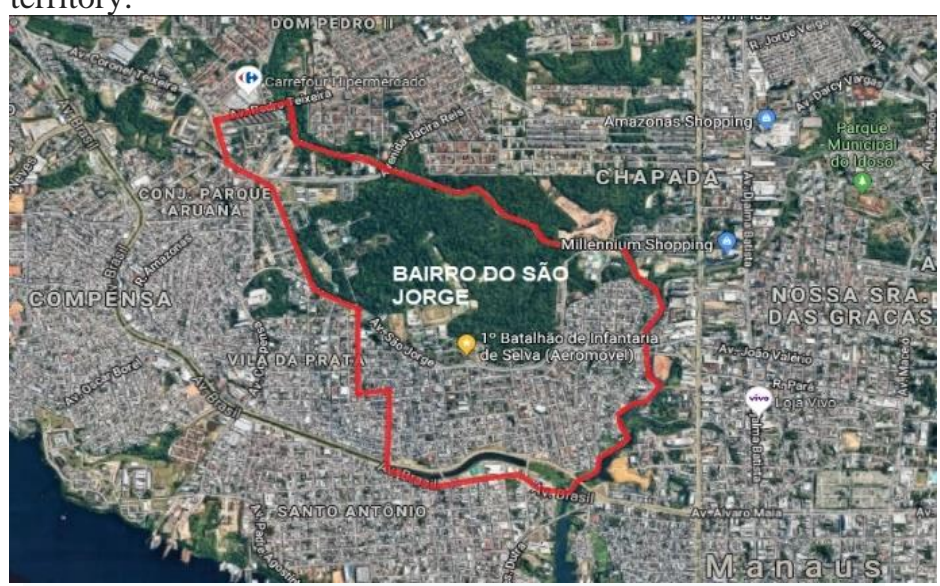

Figure 3: Geographic localization of the territory of São Jorge neighborhood in Manaus.

Source: Adapted from [18].

It is noted that only a part of the stream was conducted because the length of this stream is huge from which it cuts through the city, passing through almost all areas of Manaus.

Figure 4 below shows the location where the collections were made for this study, in this case, the Cachoeira Grande stream, in the São Jorge neighborhood.

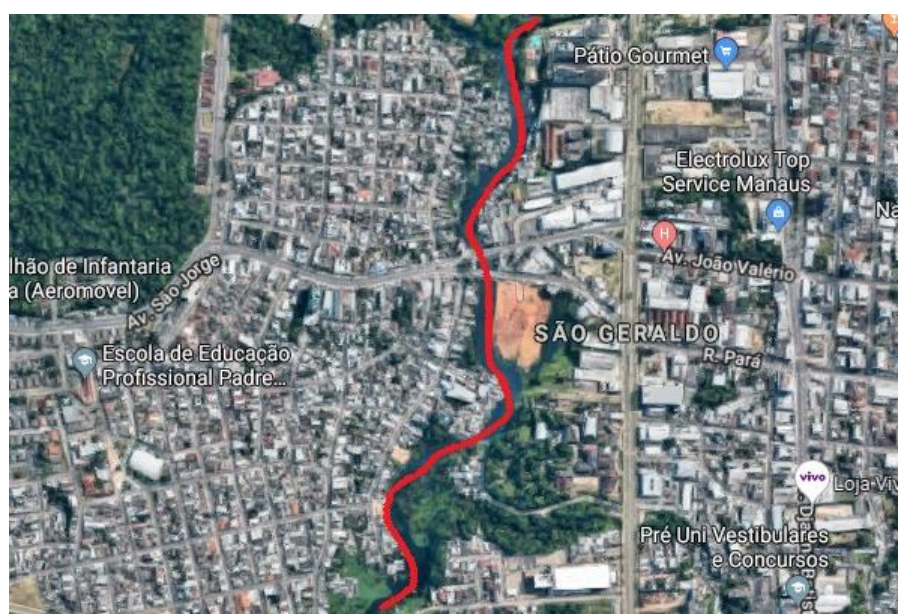

Figure 4: Place where the water samples were collected from the stream.

Source: Adapted from [18].

\section{APPLICATION OF STUDY}

\section{IV.1 SAMPLING}

The procedures adopted for the analysis of physical, chemical and microbiological parameters of the collected water meet an empirical investigation model, based on testing procedures and controls of some monitoring study variables used in laboratories.

Figure 5 below points out the collection points for the analysis of the water quality of the Cachoeira Grande stream.

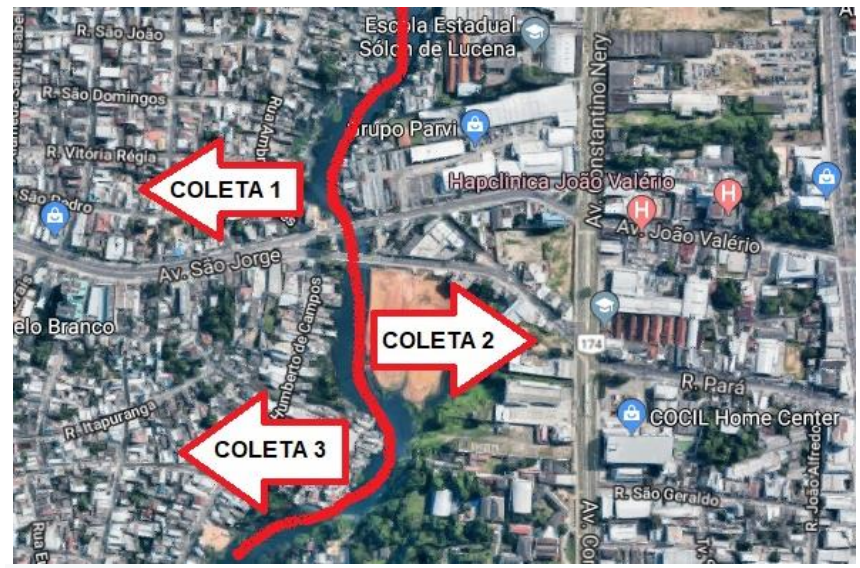

Figure 5: Collection points for water quality analysis of the Cachoeira Grande stream.

Source: Adapted from [18].

\section{IV.2 WATER CHARACTERISTICS, MONITORING AND ANALYSIS VARIABLES.}

The water analysis can be defined in 3 categories [8]:

a) Physical tests: indicate properties detectable by the senses;

b) Chemical tests: determine the quantities of mineral and organic substances that affect water quality;

c) Microbiological tests: show the presence of bacteria and other microorganisms, characteristics of fecal contamination.

\section{IV.2.1 PHYSICAL ANALYSIS.}

For the physical analysis of the water collection points of the stream, the following characteristics were observed and recorded color, turbidity, total solids (dissolved or suspended), odor and taste.

\section{IV.2.2 MICROBIOLOGICAL ANALYSIS.}

At this stage of this research, one can consider the most important of all analyzes. Microbiological analysis, in relation to the collected water, shows the presence or absence of pathogenic microorganisms, either by fecal contamination (human or animal feces) and / or indicators of sewage contamination, which can be by a series of intestinal pathogens., whether bacteria, viruses or parasites called coliforms. The major concern is that they can cause various diseases of bacterial origin such as diarrhea, typhoid fever, intestinal infection, bacillary dysentery, acute gastroenteritis, cholera, including death.

[8] Drinking and treated water should not contain pathogenic microorganisms. In practice this means that it should not be possible to detect the presence of any coliform in any 100 ml sample.

\section{IV.2.3 CHEMICAL ANALYSIS.}

In the chemical analysis of the water it evaluates the presence of a selected group, where it can be identified: the Hydrogen ionic Potential $(\mathrm{pH})$, the temperature, the hardness, the alkalinity, the acidity, the Dissolved Oxygen (DO) and metals, as well as Nitrogen Total (NT) and / or Total Phosphorus (PT).

\section{RESULTS AND DISCUSSION}

In research with data collection or experimental using interviews, medical records, assessments of people or animals it is necessary to insert the main results obtained with the development 
of the research. Figures and tables can be inserted. It is important to highlight that in systematic literature review research, the work may also be presented with results and discussion.

\section{V.1 WATER CHARACTERISTICS, MONITORING AND ANALYSIS VARIABLES.}

\section{V.1.1 PHYSICAL ANALYSIS.}

Table 1 below shows the characteristics of suspended solids in water is very large due to the amount of material collected, as well as the other characteristics are present in the samples, such as color, turbidity, odor and taste.

Table 1: Physical characteristics of the quality of the water collected in the Cachoeira Grande stream.

\begin{tabular}{|c|c|c|c|}
\hline $\begin{array}{c}\text { Collected Water } \\
\text { Characteristics - } \\
\text { Physics }\end{array}$ & $\mathbf{1}$ & $\mathbf{2}$ & $\mathbf{3}$ \\
\cline { 2 - 4 } & Present & Present & Present \\
\hline Color & 1,8133 & 1,6867 & 1,7600 \\
\hline Turbidity (NTU) & Present & Present & Present \\
\hline Odor & Present & Present & Present \\
\hline Flavor & \multicolumn{4}{|c|}{ Complementary Features } \\
\hline $\begin{array}{c}\text { Total Suspended } \\
\text { Solids (mg / L) }\end{array}$ & 55,8777 & 62,1111 & 41,8444 \\
\hline
\end{tabular}

Source: Authors, (2019).

\section{V.1.2 MICROBIOLOGICAL ANALYSIS.}

Table 2 below shows that the sample 3 collected in the Cachoeira Grande stream, in relation to the microbiological analysis of total and fecal coliforms, showed no presence of microorganisms; it may be because of the water current and / or being a little distant from homes or not. Further study could be certain.

Table 2: Microbiological characteristics of the water collected in the Cachoeira Grande stream.

\begin{tabular}{|l|c|c|c|}
\hline \multirow{2}{*}{$\begin{array}{c}\text { Collected Water } \\
\text { Characteristics - } \\
\text { Microbiological }\end{array}$} & $\mathbf{1}$ & $\mathbf{2}$ & $\mathbf{3}$ \\
\cline { 2 - 4 } & 1,2 & 1,8 & 1,6 \\
\hline Organic Matter (mg / L) & Present & Present & Absent \\
\hline Total Coliforms & Present & Present & Absent \\
\hline Fecal Coliforms &
\end{tabular}

Source: Authors, (2019).

\section{V.1.3 CHEMICAL ANALYSIS.}

For the chemical analysis, a conventional method available at pool and equipment stores was firstly used for the analysis of Hydrogen Potential $(\mathrm{pH})$ of which no collected samples are acceptable and may have alkalinity and / or acidity as shown in Figure 6, below.

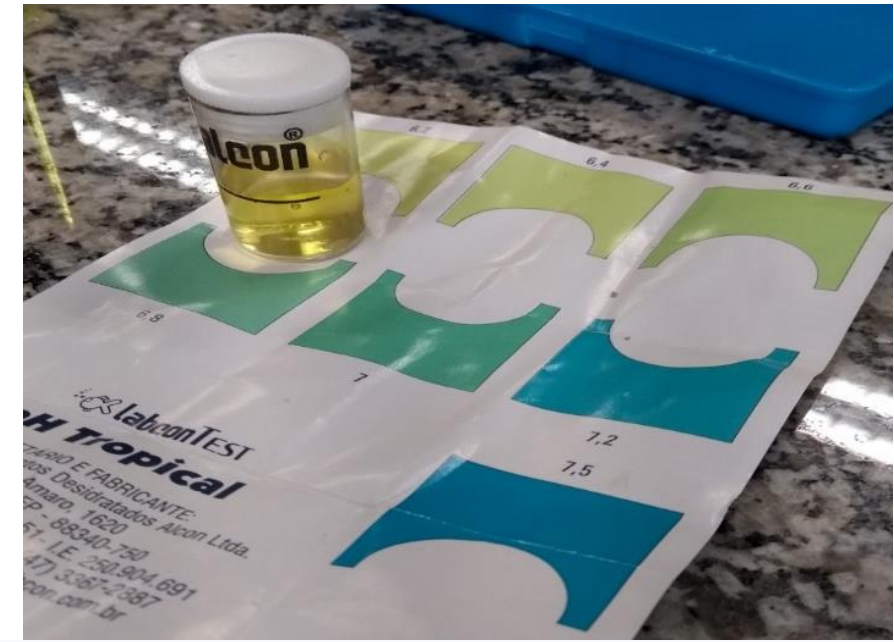

Figure 6: Preliminary chemical analysis of water $\mathrm{pH}$ by the pool method.

Source: Authors, (2019).

From this result (figure 6, above) specific analyzes were performed as shown in table 3 below.

Table 3 - Analysis of the specific chemical characteristics of the water collected in the Cachoeira Grande stream.

\begin{tabular}{|l|c|c|c|}
\hline \multirow{2}{*}{ Collected Water } & \multicolumn{3}{|c|}{ Sampling } \\
\cline { 2 - 4 } Characteristics - Chemistry & $\mathbf{1}$ & $\mathbf{2}$ & $\mathbf{3}$ \\
\hline Temperature $\left({ }^{\circ} \mathrm{C}\right)$ & 29,0 & 27,5 & 28,5 \\
\hline Dissolved Oxygen - OD (mg/L) & 2,6 & 3,0 & 2,8 \\
\hline Total Nitrogen (NT) & Present & Present & Present \\
\hline Total Phosphorus (PT) & Present & Present & Present \\
\hline Toughness (mg/ L) & 17,1 & 14,6 & 16,0 \\
\hline Hydrogen potential (pH) & 4,8 & 8,6 & 4,0 \\
\hline Alkalinity (mg/ppm) & 140 & 160 & 130 \\
\hline Acidity & Present & Absent & Present \\
\hline Metals & Absent & Present & Present \\
\hline
\end{tabular}

Source: Authors, (2019).

\section{CONCLUSIONS}

Having clean water is essential for the survival of every living being on this planet. Not knowing if it has a good quality for consumption is a death sentence.

In previous centuries, when there was no treatment of sewage, drainage, septic tank, among other methods and means of treatment of water, many people died due to numerous diseases transmitted by contaminated water be it coliforms, acidity, alkalinity and so on. we saw in this research. Even in the current century, a recent study by the Brazilian Institute of Geography and Statistics (IBGE) shows that the state of Amazonas is the 5th state of Brazil without water and / or sewage treatment, which becomes alarming and worrying for the population. in relation to public health in the state, of which most of the responsible public agencies deal with this situation with much disregard.

With this in mind, this research found what was already obvious, a poor quality of water from the streams (igarapés) that run through the state capital where $80 \%$ of them serve as city sewage without any treatment. Less than $40 \%$ of the sewage water is treated and / or returned to the population to be consumed again, which results in a concern about the health and safety of the residents of the city of Manaus and especially of the studied area, São Jorge neighborhood. The results found here were already 
expected, but the technical feasibility of this research aims at this concern, emphasizing, even if it is for a minority of the population, the kind of treatment that residents of the Amazonian capital generally treat our most precious asset, Water.

\section{REFERENCES}

[1] Vaquero, M. P.; Toxqui, L. Agua para La salud. Pasado, presente y futuro. In: Azcona, A.C.; Fernandez, M.G. (Ed.). Propiedades y funciones biológicas del água. Madrid: CSIC. 2012. p. 63-78.

[2] Razzolini, M. T. P.; Gunther, W. M. R. Impactos na Saúde das Deficiências de Acesso a Água. Revista Sociedade e Saúde. São Paulo. v.17, n.1, p. 21-32. 2008.

[3] Sá, José A. C. A.; Campos, Luciana R. O Direito e a Gestão das Águas. In: Campos, Nilson; Studart, Ticiana M. C. (Eds.) Gestão das Águas: princípios e práticas. 2. ed. Porto Alegre: ABRH, 2003. p. 216-237.

[4] Bettega, J. M. P. R.; Machado, M.R.; Presibella, M.; Baniski, G.; Barbosa, C. A. Métodos analíticos no controle microbiológico da água para consumo humano. Ciênc. Agrotec. [Internet]. 2006 [cited 2016 Jul 25];30 (5): 950- 954. Available in: http://www.scielo.br/pdf/cagro/ v30n5/v30n5a19.pdf.

[5] Esteves, F. A. Fundamentos de limnologia. 2 ed. Rio de Janeiro: Interciência, 1998. BRAGA, Benedito et al. Introdução à Engenharia Ambiental. 2. ed. São Paulo: Pearson Prentice Hall, 2005 .

[6] Tucci, C. E. M., Hidrologia: ciência e Aplicação. 4. ed. Porto Alegre: Editora da UFRGS/ ABRH, 2007.

[7] Merten, G. H.; Minella, J. P. Qualidade da água em bacias hidrográficas rurais: um desafio atual para a sobrevivência futura. Agroecologia e Desenvolvimento Rural Sustentável. Porto Alegre, 2002.

[8] Portal Kasvi. Análise de água e monitoramento da qualidade. 2018. Disponível em:< https://kasvi.com.br/analise-de-aguamonitoramento-qualidade/>. Accessed in: June, 2019.

[9] Brasil. Lei $n^{\circ} 6.938$, de 31 de agosto de 1981. Dispõe sobre a Política Nacional do Meio Ambiente, seus fins e mecanismos de formulação e aplicação, e dá outras providências. Available in: < http://www.planalto.gov.br/ccivil_03/leis/L6938.htm>. Accessed in: July, 2019.

[10] Meybec, M.; Helmer, R. An introduction to water quality. In: Chapman, D. Water Quality Assessments - A Guide to Use of Biota, Sediments and Water in Environmental Monitoring. 2nd Edition Cambridge: University Press, 1996.

[11] Souza, J. R.; Moraes, M. E. B.; Sonoda, S. L.; Santos, H. C. R. G. A importância da qualidade da água e os seus múltiplos usos: Caso rio Almada, sul da Bahia, Brasil. REDE - Revista Eletrônica do Prodema, v.8, n.1, p. 26-45, abr. 2014, Fortaleza, Brasil, ISSN: 1982-5528.

Available

in:

<http://www.revistarede.ufc.br/rede/article/view/2017/51>.

Accessed in: July, 2019.
[12] Esteves, F. A. Fundamentos de limnologia. 3ed. Rio de Janeiro: Interciência, 2011.

[13] Carvalho, D. F.; Mello, J. L. P.; Silva, L. D. B. Hidrologia: irrigação e drenagem. 2007. Available in: [http://www.ufrrj.br/institutos/it/deng/jorge/downloads/APOSTIL A/LICA\%20Parte\%201.pdf]. Accessed in: June, 2019.

[14] Tucci, C.E.M. Usos e impactos dos recursos hídricos. In: Tucci, C.E.M.; Mendes, C. A. Avaliação ambiental integrada de bacia hidrográfica. São Paulo: Ministério do Meio Ambiente (Secretaria de Qualidade Ambiental)/ Rhama Consultoria Ambiental, 2006.

[15] Rebouças, A. C. Água doce no mundo e no Brasil. In: Rebouças, A. Da C.; Braga, B.; Tundisi, J. G. Águas doces no Brasil capitais ecológicos usos e conservação. 3 ed. São Paulo: Escrituras, 2002. p. 269-324.

[16] Brasil. Resolução CONAMA n. ${ }^{\circ}$ 357, de 17 de março de 2005. Dispõe sobre a classificação dos corpos de água e diretrizes ambientais para o seu enquadramento, bem como estabelece as condições e padrões de lançamento de efluentes, e dá outras providências. Diário Oficial da República federativa do Brasil, Brasília, Seção 1, p. 58-63. 2005.

[17] Instituto Brasileiro De Geografia E Estatística, IBGE. Censo 2010: Indicadores de Bairros - Região Norte. Available in:< https://pt.wikipedia.org/wiki/S\%C3\%A3o_Jorge_(Manaus)>. Accessed in: July, 2019.

[18] Google Maps, 2019. 